Bolm Inst. oceanogr., S Paulo, 35(2):115-122, 1987

\title{
THE CONTRIBUTION OF ISOPODS IN THE FEEDING OF sympterygia spp (PISCES: RAJIDAE) WITH A DESCRIPTION OF Ancinus gaucho $s \mathrm{p} . \mathrm{n}$. (ISOPODA: SPHAEROMATIDAE)
}

Ana Maria Setubal PIRES

Instituto Oceanográfico da Universidade de São Paulo (Caixa Postal 9075, 01051 São Paulo, SP)

\begin{abstract}
The present paper deals with the isopods present in the stomach content of Sympterygia acuta and S. bonapartei, two species of Rajidae frequently found along Rio Grande do Sul coast. Eight species of isopods were found in the stomachs analysed, and Ancinus gaucho sp.n. showed to be an important food resource for the fishes, especially for S. bonapartei. The difference found in the diet composition of both species of skates seems to reflect a non selective feeding of the fishes on distinct benthic communities. The description of Ancinus gaucho is also furnished herein as well as a key to the known species of the genus.
\end{abstract}

Descriptors: Stomach content, New species, Taxonomy, Identification keys, Ancinus gaucho, Isopoda, Rajidae, Rio Grande do Sul, Brazil.

Descritores: Conteūdo estomacal, Espécie nova, Taxonomia, Chaves de identificação, Ancinus gaucho, I sopoda, Rajidae, Rio Grande do Sul, Brasil.

Introduction

During 1981-1984, six cruises were performed to the continental shelf of Rio Grande do Sul, southern Brazilian coast (between $30^{\circ} 34^{\prime} \mathrm{S}$ and $33^{\circ} 49^{\prime} \mathrm{S}$ ) on board of R/V "Atlântico Sul" and at Cassino Beach. Among the material trawled by a bottom dredge there were many specimens of Sympterygia acuta Garman, 1877 and S. bonapartei Muller \& Henle, 1841, two species of Rajidae frequently found in those waters. The isopods obtainet in 55 stomachs of both species were sent to me for identification by E. L. Queiroz who studied the biology and distribution of those skates (Queiroz, 1986).

Crustaceans have been frequently reported as significant food for bottom Rajidae (Capapé, 1975, 1977; Holden \& Tucker, 1974). After Basescu \& Queiroz (1985) isopods were the fourth and third important item in the diet of Sympterygia acuta, and S. bonapartei, respectively. Among the material I

Contr. no. 672 do Inst. oceanogr. da Usp. studied there was one species frequent and abundantly found in the stomach of S. bonapartei, and described herein as Ancinus gaucho sp. $\mathrm{n}$.

The genus Ancinus comprises six described species distributed in the tropical West Atlantic and East Pacific coasts. It is housed in the subfamily Ancininae erected by Iverson (1982), and has Bathycopea Tattersall as its sister-group.

The last revision of Ancinus is that of Glynn \& Glynn (1974), which summarized the knowledge of the genus and keyed the species. Kensley \& Schotte (1987) added the sixth species to the group.

Ancinus gaucho sp.n. is the seventh species of the genus and the second and southern species reported for the Brazilian waters.

\section{Results}

Eight species of isopods were obtained, totaling 158 specimens in good condition besides many fragments partially digested. 
They were:

Ancinus gaucho sp. $n$.

Anilocra sp.

Lironeca redmanni Leach, 1818

Macrochiridotea robusta Bastida \& Torti, 1969

Nerocila acuminata Schioedt \& Meinert, 1883

Serolis laevis Richardson, 1911

Serolis polaris Richardson, 1911

Synidotea marplatensis Giambiagi, 1922

Nearly $75 \%$ of the samples studied were from stomach content of adult skates. The analysis of those content showed that the size and sex of the fish seems not to be related with the size and species of the isopod ingested. On the other hand, the results indicate a quali and quantitative difference on the isopods found in the stomach of Sympterigya acuta and $S$. bonapartei. This fact probably reflects a non selective feeding of the skates on distinct benthic communities.

S. acuta presented a greater diversity of isopods ( 8 species), being Synidotea marplatensis the most numerous and frequent animal followed by Serolis laevis and Nerocila acuminata (Table 1). On the other hand, S. bonapartei presented only four species of isopods in the stomach, and Ancinus gaucho sp. $n$. was decisively the most abundant and frequent. S. marplatens is showed to be one of the most consummed isopod for both species of Sympterygia, being present in more than $25 \%$ of the stomachs having those crustaceans.

Ancinus gaucho sp.n. (Figs 1-21)

Types. Brazil. Rio Grande do Sul, between $33^{\circ} 34^{\prime} \mathrm{S}, 50^{\circ} 03^{\prime} \mathrm{W}$ and $33^{\circ} 49^{\prime} \mathrm{s}$, $52^{\circ} 46^{\prime} \mathrm{W}, 23-30$. VIII. 1983, E. L. Queiroz leg., in stomach of Sympterygia bonapartei (holotype male, $8.4 \mathrm{~mm}$ long, MZSP cat. no $8872 ; 40$ paratypes ( 30 danified) MZSP cat. n? $8873 ; 46$ paratypes (30 danified) IOUSP cat. no 212); same locality, 08-19. IX. 1983, E. L. Queiroz leg., in stomach of Sympterygia acuta (5 paratypes, MZSP cat. no 8874).

\section{Diagnosis}

Body breadth nearly 0.55 of length; pleotelson broadly rounded, apex excavate; uropod slightly surpassing pleotelson tip; pereopod II with dactylus reaching base of propodus; pleopod 5 with three squamiferous protuberances; length: $7.0-8.4 \mathrm{~mm}$ (male), $4.8-5.2 \mathrm{~mm}$ (female).

Description. Adult male with body nearly 1.9 times longer than wide, major width on pereonites 2 and 3 , yellowish with dark brown chromatophores spread out, some translucid granules placed at distal margins. Head $2 / 3$ as wide as pereonite $I$, distal margins with

Table 1. Abundance (No.) and frequence of occurrence (Fo) of the isopods present in the stomach content of Sympterygia acuta and $S$. bonapartei (Pisces: Rajiformes)

\begin{tabular}{lcccc}
\hline $\begin{array}{l}\text { Species of } \\
\text { Isopoda }\end{array}$ & No. acuta & S. bonapartei \\
\hline Ancinus gaucho sp.n. & 4 & 12 & No. & Fo $(\%)$ \\
Serolis laevis & 12 & 16 & $67 *$ & 62 \\
Serolis polaris & 13 & 3 & 3 & 9 \\
Macrochiridotea robusta & 1 & 3 & 0 & 0 \\
Synidotea marplatensis & 69 & 44 & 0 & 0 \\
Nerocila acuminata & 5 & 16 & $36 *$ & 25 \\
Lironeca redmanni & 2 & 6 & 0 & 0 \\
Anilocra sp & 2 & 3 & 8 & 12 \\
\hline
\end{tabular}

* Several more individuals in advanced process of digestion 

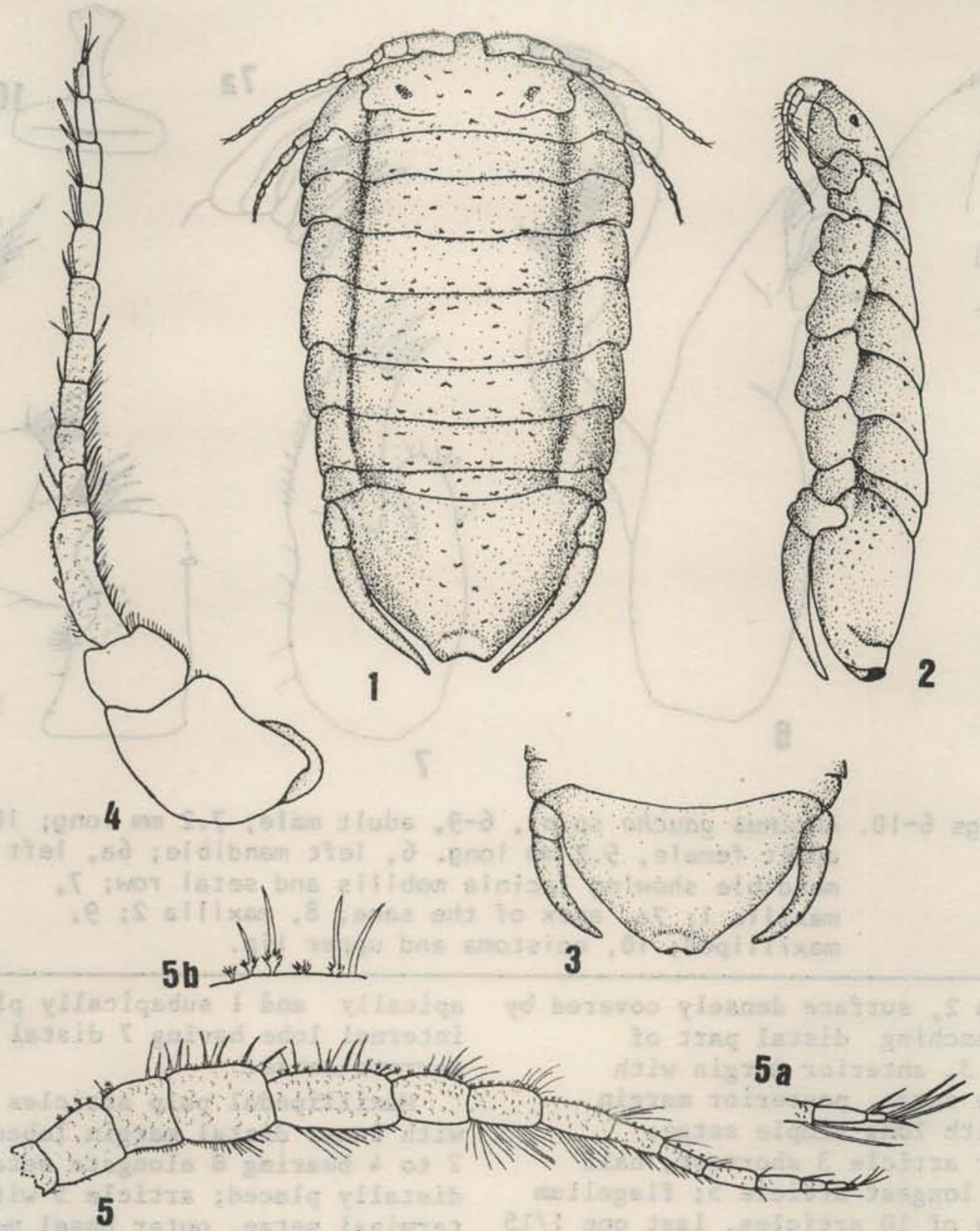

Figs 1-5. Ancinus gaucho sp.n., $1-2$, holotype adult male, $8.4 \mathrm{~mm}$ long; 3 , adult female, $5.2 \mathrm{~mm}$ long; $4-5$, adult male, $7.2 \mathrm{~mm}$ long. 1, dorsal view;

2, lateral view; 3, pleotelson apex; 4, antenna

$1 ; 5$, antenna 2 ; 5 a, apex of the same; $5 b$, setae at dorsal margin of antenna 2 .

submedial lobe, lateral margin anteriorly excavate, posterior suture lines spaced each other by twice the interantennal process width; interantennal process nearly half wider than long; eyes small with few ommatidea. Pereon slightly decreasing in width from pereonite III to VII; pereonite V longest, pereonites III, IV and VI almost equal in length, longer than pereonites II and VII; epimera completely fused to pereonites. Pleon consisting of one free segment plus pleotelson; pleotelson almost globose, $2 / 5$ wider than long, apex excavate bent downwards.

Antenna 1 reaching pereonite 2 , with many scales at surface; peduncle 3-articulated, first article nearly twice second article length, many setae laterally placed; flagellum of 11 articles, one aesthetasc present on articles 4 to 9 , lateral margins of articles $1-4$ densely setose. 


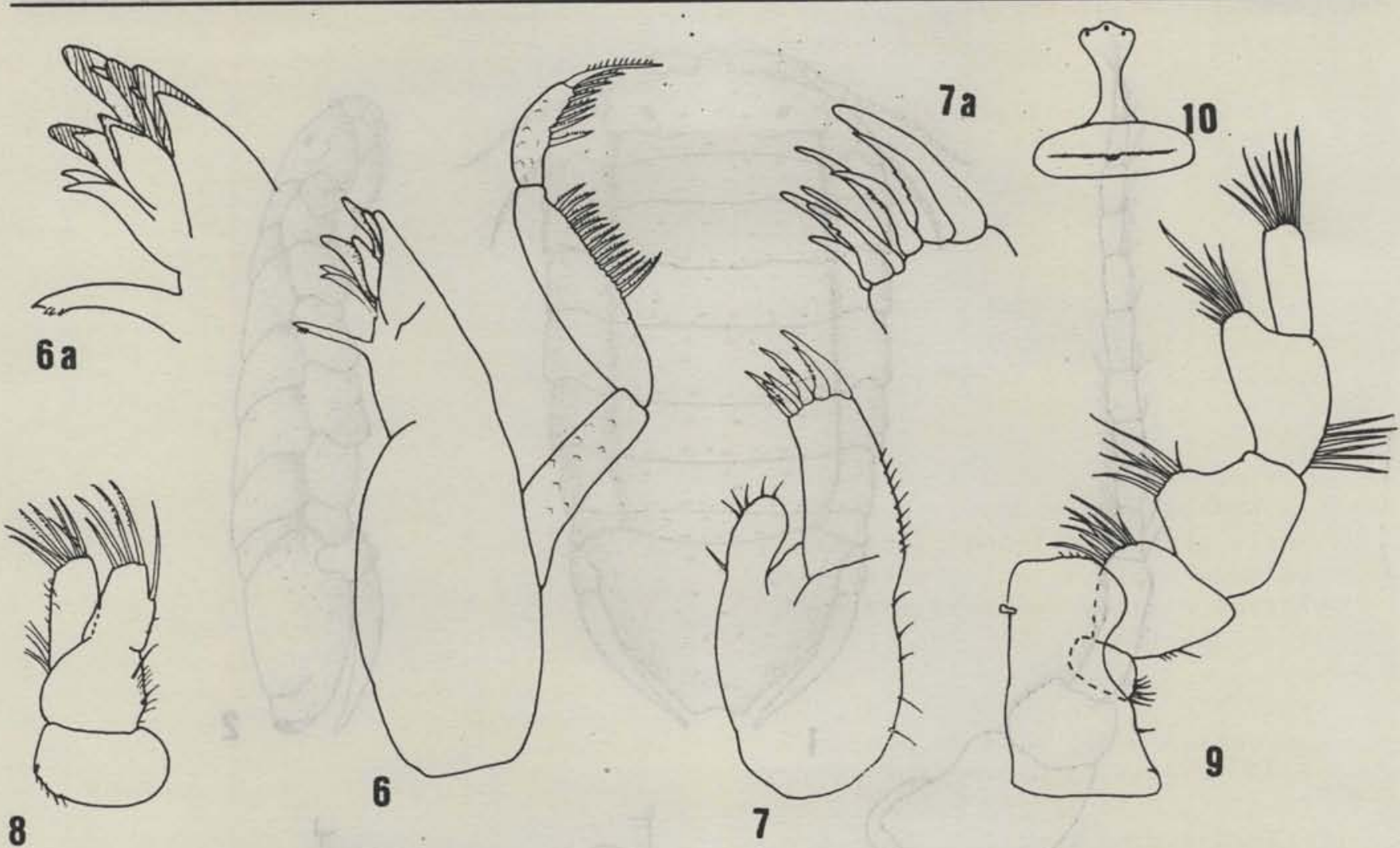

Figs 6-10. Ancinus gaucho sp.n., 6-9, adult male, $7.2 \mathrm{~mm}$ long; 10, adult female, $5.2 \mathrm{~mm}$ long. 6 , left mandible; $6 \mathrm{a}$, left mandible showing lacinia mobilis and setal row; 7 , maxilla $1 ; 7 a$, apex of the same; 8 , maxilla $2 ; 9$, maxilliped; 10, epistoma and upper lip.

Antenna 2, surface densely covered by scales, reaching distal part of pereonite 3 , anterior margin with penicilate setae, posterior margin fringed with long simple setae; peduncular article 3 shortest, half length of longest article 5; flagellum consisting of 10 articles, last one $1 / 15$ as long as first one.

Epistoma elongate with distal margin sinuose, lateral margins strongly convex; upper lip ovoid, 3 times wider than long.

Mandible having long palp, article 2 twice longer than article 3 , anterior margins of both bearing 14 and 7 pectinate setae, respectively; incisive process strong with 3 highly

sclerotized cusps, lacinia mobilis with 2 cusps present on both mandibles; setal row with 2 strong setae, proximal bifurcate distal one apically serrate.

Maxilla 1 exopodite with 8 teeth, some serrate others smooth; endopodite reduced, apex rounded.

Maxilla 2 bilobed, each lobe with a dorso-ventral hairy area, external lobe with 5 minutely serrate setae, 4 apically and 1 subapically placed; internal lobe having 7 distal minutely serrate setae.

Maxillipedal palp articles 3 and 4 with inner distal margin lobed; articles 2 to 4 bearing 8 elongate setae, inner distally placed; article 5 with 8 terminal setae, outer basal margin of articles 1,2 and 4 bearing elongate setae placed distally on inner margin of articles 2 to 4 , basally on outer margin of article 4 and apically on terminal article; endite reaching half palp article 2 length, with 1 coupling hook.

Pereopod I subchelate, shorter than others pereopods, with ischium half length of basis and $2 / 5$ longer than merus, carpus nearly $1 / 6$ length of propodus bearing two long setae inner: distally placed; propodus broad, about 1.3 times longer than wide, inner margin with a row of quitinous short setae, the most distal longer than carpus; dactylus with apex reaching the base of propodus, nearly 4 times narrower than preceding article, inner margin bearing a row of 


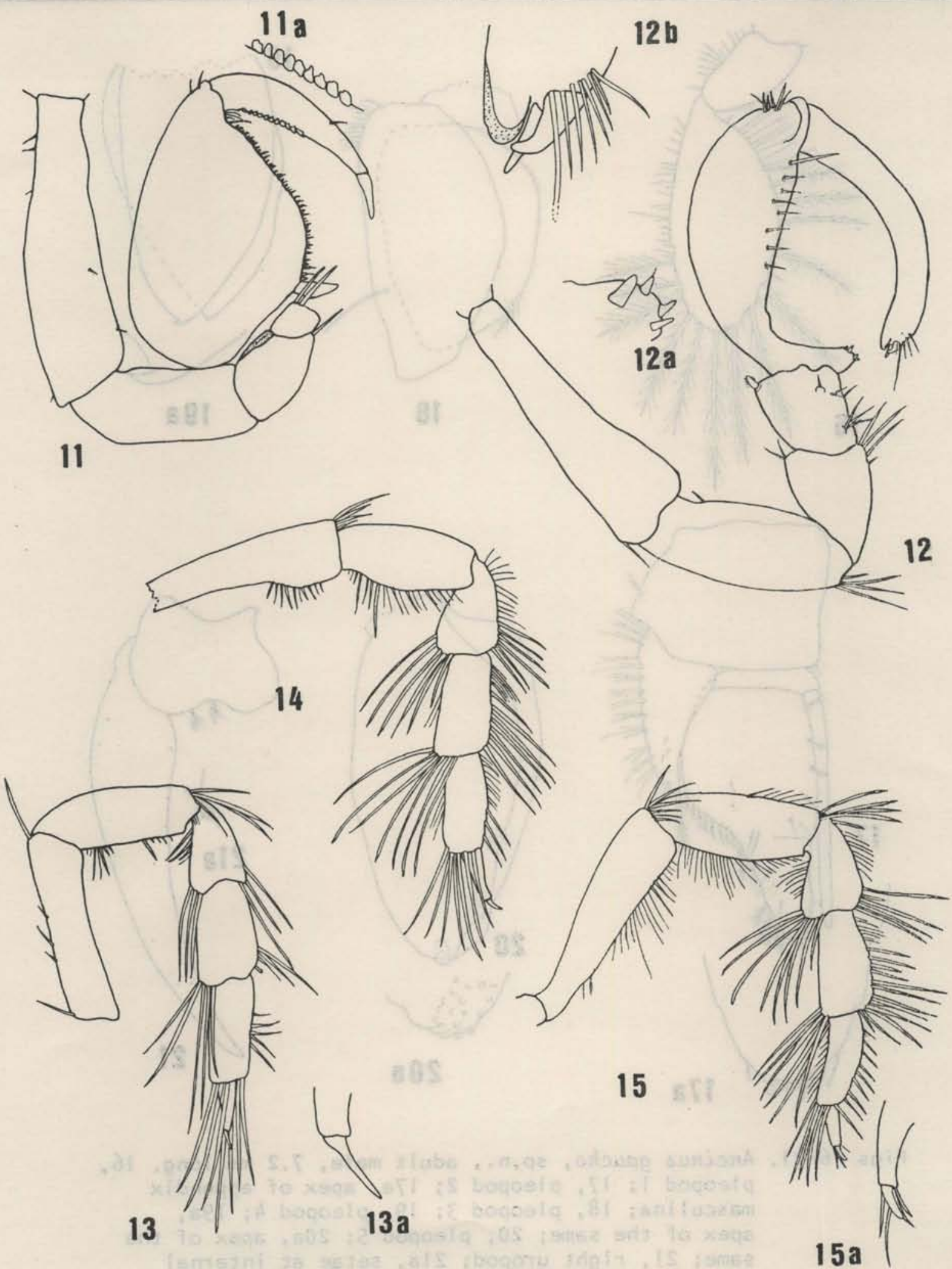

Figs 11-15. Ancinus gaucho sp. n., 11, 12, 14, 15, adult male, $7.2 \mathrm{~mm}$ long; 13, adult female, $5.2 \mathrm{~mm}$ long. 11 , pereopod I; 11 a, short quitinous setae at ventral margin of propodus; 12, pereopod 11 ; 12a, basal process of propodus showing four quitinous setae; $12 b$, apex of dactylus; 13, pereopod 11; 13a, apex of the same; 14 , pereopod $111 ; 15$, pereopod VII; $15 a$, apex of the same. 

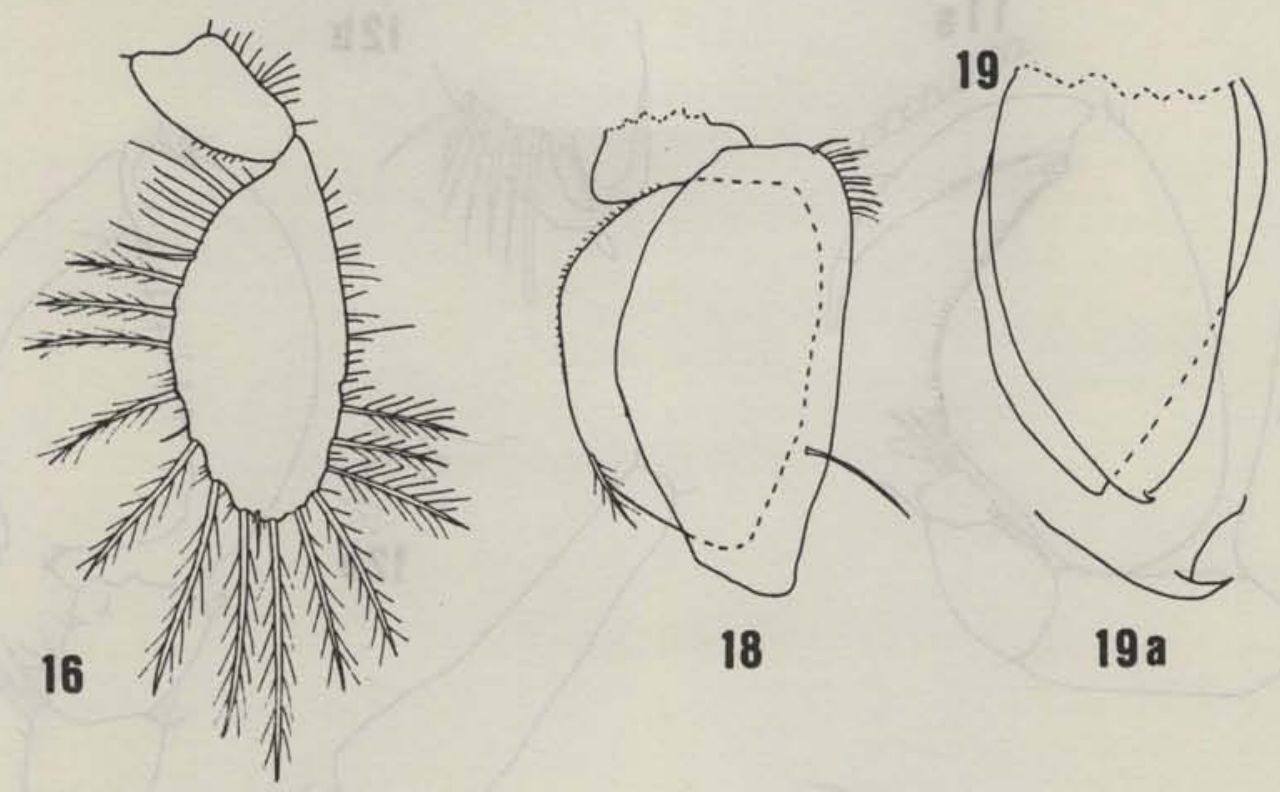

18

19 a
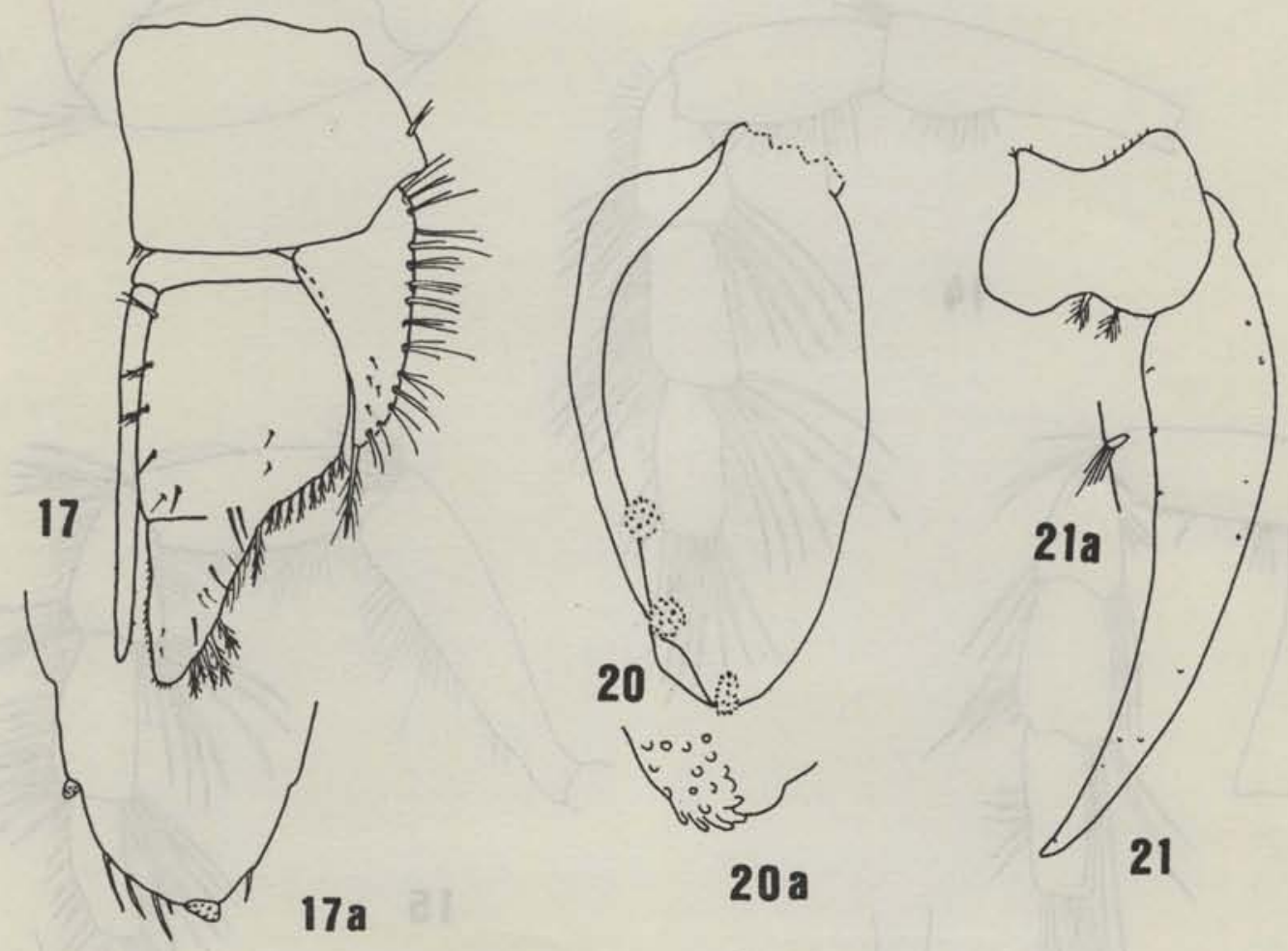

Figs 16-21. Ancinus gaucho, sp.n., adult male, $7.2 \mathrm{~mm}$ long. 16, pleopod 1; 17, pleopod 2; 17a, apex of appendix mascul ina; 18, pleopod 3; 19, pleopod 4; 19a, apex of the same; 20; pleopod 5; 20a, apex of the same; 21 , right uropod; 21 a, setae at internal margin of the same.

short, flattened plates at inner proximal half.

Pereopod II subchelate, longer than others, sexually dimorphic; ischium as long as propodus, merus of the same length as carpus; carpus with large quitinous serrate setae at outer distal angle; inner margin of propodus bearing four short spines at proximal corner and some sparse setae at distal 2/3; dactylus curved reaching base of propodus, basal part subequal in width to narrowest part of propodus, tipped with a small curved unguis and an 
internal quitinous area.

Pereopods III-VII alike, heavely setose, dactylus longer than half length of propodus, tipped with curve unguis.

Pleopod 1 uniramous with 13 long plumose setae and many simple setae along margins.

Pleopod 2 exopod slightly shorter than protopodite, half length of endopod, outer margin having many tufts of long setae, one plumose setae distally placed; endopod wider at basal 4/7 tapering distalwards, basal part nearly 3.3 times wider than distal part, incomplete suture line placed in the first $2 / 3$ of the lamina; appendix masculina slightly shorter than endopod, tipped with small microtuberculate denticle, smaller denticle subapically placed at inner margin.

Pleopod 3, endopod twice as long as wide, some setae placed at basal inner corner, nearly $1 / 6$ longer than exopod; exopod $1 / 3$ longer than wide, outer margin with upper half having a row of short setae and distal half with one plumose setae.

pleopod 4, endopod slightly longer than exopod tipped with curved process.

Pleopod 5 with both laminas subequal in length, exopod having three

squamiferous protuberances: two at inner margin, one distally placed.

Uropod with protopod as long as exopod major width, having outer margin convex, others excavate; exopod curved inward, 4.5 times longer than wide, wider on basal quarter, tapering slowly distalward, apex narrowly round, few penicilate setae placed basally at inner margin.

\section{Remarks}

Ancinus is a genus sexually dimorphic. Females are easily distinguished from males by having smaller adult length, pereopod II ambulatory, uropods not reaching pleotelson apex.

Etymology: Named for the "gauchos", the inhabitants of Rio Grande do Sul, Brazil.

\section{Discussion}

The first species of Ancinus described for the Southern hemisfer is Ancinus brasiliensis Castro, 1959 obtained from Rio de Janeiro, Brazil. Ancinus gaucho sp.n., collected at Rio Grande do Sul extends the distribution of the genus far south, to the subtropical South Atlantic coast.

Ancinus gaucho is easily separated from A. brasiliensis by presenting a wider body, dactylus shorter than propodus, pleotelson broad with apex broadly round and excavate, exopod of pleopod 5 with three squamiferous protuberances, uropod longer than pleotels on and curved inward.

The other species morphologically more similar to $A$. gaucho are A. panamensis Glynn \& Glynn, 1974 and A. belizensis Kensley \& Schotte, 1987. These three species agree in having body as wide as or wider than half its length and pleotelson apex broadly round. However $A$. gaucho and $A$. panamensis differ from $A$. belizensis by presenting the dactylus of pereopod II in males equal or shorter than propodus. The other group of species is composed by A. depressus (Say, 1818), A. brasiliensis and $A$. seticomvus Trask, 1970, which have body elongate, major width less than half the body length, dactylus longer than propodus, pleotelson apex narrow and acute. Ancinus granulatus Holmes \& Gay, 1909 does not belong to any of these groups since it has characteristics of both, such as body wide, pleotelson apex acute and dactylus longer than propodus. Other differences among the species can be found in the key to the species of Ancinus done by Glynn \& Glynn (1974) modified and emended herein to include Ancinus belizensis and Ancinus gaucho sp. $\mathrm{n}$.

\section{Key to the species of Ancinus}

1a. Body as broad as half its length; pleotelson distally broad or acute........................

1b. Body elongate, as long as twice its width; pleotelson distally narrow...5.

$2 a$. Apex of pleotelson broadly rounded or truncate; ridges absent from lateral margins of pereonites and epimera; male pereopod II with dactylus closing on propodus or carpus; body surface granulated or smooth; eyes not elevated on swellings..................... 
2b. Apex of pleotelson narrow, acute, truncate; ridges present on lateral margins of pereonites and epimera; male pereopod II with dactylus closing on carpus; body surface densely granulated; eyes elevated on swellings............. granulatus

3a. Apex of pleotelson round; pereopod II of male with dactylus closing at midlength of propodus or at carpus......................

3b. Apex of pleotelson truncate; pereopod II of male with dactylus closing at base of propodus; propodus process with four short spines............... gaucho sp.n.

4a. Sutural line separating head from pereonite I interrupted, about half the distance between eye and rostrum; pereopod II of male with dactylus closing at midlength of propodus; propodus process with four to eigth setae; body surface unpitted............... panamens is

4b. Sutural line separating head from pereonite I complete; pereopod II of male with dactylus closing on the basal lobe of propodus; propodus process with three stubby spines; body surface strongly pitted........ .................... belizensis

5a. Maxilliped with two coupling hooks; uropod longer or shorter than pleotelson...................6

$5 b$. Maxilliped with one coupling hook; uropod equal to pleotelson........... ...................... depressus

6a. Incisive process with three teeth; pleopod 5 exopod with four squamiferous protuberances; uropod shorter than pleotelson............. .................. brasiliensis

$6 \mathrm{~b}$. Incisive process with four teeth; pleopod 5 exopod with five squamiferous protuberances; uropod longer than pleotelson. A. seticomvus

\section{References}

BACESCU, M. \& QUEIROZ, E. L. de 1985. The contribution of Cumacea in the feeding of the Rajidae Sympterygia acuta and $S$. bonapartei from Rio Grande do Sul - S. Brazil. Trav. Mus. Hist. nat. "Gr. Antipa", 27:7-18.
CAPAPE, C. 1975. Contribution à 1a biologie des Rajidae des côtes tunisiennes. IV. Raja clavata: régime alimentaire. Annls Inst. Michel Pacha, 8:16-32.

biologie des Rajidae des côtes tunisiennes. 6. Raja asterias Delaroche, 1809. Régime alimentaire. Bu11. Inst. natn. scient. tech. Océanogr. Pêche Salammbô, 4(2-4): 319-332.

GLYNN, P. W. \& GLYNN, C. S. 1974. On the systematics of Ancinus (Isopoda, Sphaeromatidae), with the description of a new species from the tropical eastern Pacific. Pacific Sci, , 28(4):401-422.

HOLDEN, M, J. \& TUCKER, R. N. 1974. The food of Raja clavata Linnaeus 1758, Raja montagui Fowler 1810, Raja naevus Muller et Henle 1841 and Raja brachyura Lafont 1873 in British waters. J. Cons. perm. int. Explor. Mer, 35(2): 189-193.

IVERSON, E. W. 1982. Revision of the isopod family Sphaeromatidae (Crustacea: Isopoda: Flabellifera) I. Subfamily names with diagnoses and key. J. crustacean Biol., 2(2):248-254.

KENSLEY, B. \& SCHOTTE, M. 1987. New records of isopod Crustacea from the Caribbean, the Florida Keys, and the Bahamas. Proc. biol. Soc. Wash., $100(1): 216-247$.

QUEIROZ, E. L. de 1986. Estudo comparativo da alimentação de Sympterygia acuta Garman, 1877 e $S$. bonapartei Muller \& Henle, 1841 (Pisces: Rajiformes) com relação a: distribuição, abundância, morfologia e reprodução nas águas litorâneas do Rio Grande do Sul - Brasil. Dissertação de mestrado, Universidade do Rio Grande, RS. 137p. + 2 ann. (unpublished). 